\title{
Democracy and Discourse in an Integrating Europe and a Globalising World
}

\author{
Vivien A. Schmidt*
}

\begin{abstract}
Globalisation and Europeanisation represent challenges not only to national economies and institutions but also to national legitimating discourses. This paper first outlines the theoretical requirements for such discourse, by considering it along two dimensions: ideational, which encompasses cognitive and normative functions, and interactive, which encompasses co-ordinative and communicative functions. The paper illustrates these through empirical discussions of the post-war construction of discourses in France, Britain and Germany. It then examines how the discourses have responded to the challenges to traditional conceptions of economic organisation, social welfare, and political democracy from European and globally-related economic and institutional changes. The paper concludes that while France remains in search of a legitimating discourse, Britain is in the process of renewing its Thatcherite discourse, and Germany is in the process of recasting its post-war liberal social-democratic discourse. ${ }^{1}$
\end{abstract}

Globalisation and European integration have been major forces for change in national economies and institutions, promoting the transformation of government management of the economy and policies toward business, of business and its relationship to government and labour, of national institutional structures and the balance of powers, and of national policy-making processes and patterns of governance. In responding to these global and European forces, some European countries have done better than others in accommodating the resulting economic and institutional changes. Why is this so?

Certainly, a large part of the answer lies in how successfully Member States have adjusted their economies and adapted their institutions in response to global and European pressures, which relates to questions of the size and strength of national economies and the timing and extent of liberalisation as well as to questions of the

* Dept. of International Relations, Boston University.

${ }^{1}$ An earlier version of this article was published as 'Democrazia e Discorso Pubblico: La Sfida dell Integrazione Europea e della Globalizzazione', (1999) 2 Rivista Italiana di Scienza Politica. This is also a revision of a paper prepared for delivery for the American Political Science Association National Meetings (Boston, 3-6 September, 1998) and for the workshop, Globalization, Europeanization, and Political Economy in Europe' at the University of California, Berkeley (24-25 April, 1998). I would like to thank Steven Weber, John Campbell, Paulette Kurzer, Chris Ansell, Nick Ziegler, Elliot Posner and Vanna Gonsalez for their comments. I would also like to thank Fritz Scharpf, Wolfgang Streeck and Renate Mayntz at the Max Planck Institute in Cologne, Yves Mény, Martin Rhodes and Maurizio Ferrera at the European University Institute, and Beate Kohler-Koch at the University of Mannheim. 
organisation and operation of national institutions and their fit with European institutional structures and patterns of policy-making. But it is also related to the ability of Member States to legitimate the economic adjustments and institutional adaptations by way of public discourse.

As globalisation and Europeanisation proceed, the need for such a legitimating discourse to foster public acceptance of change only increases. Nothing is inevitable, despite the seeming inescapability from global economic imperatives and the apparent inexorability of European institutional integration. Nations, just as individuals, exercise choice. And the future of globalisation and European integration depends upon nations and their citizens continuing to choose openness and integration. For this, however, the public has to be convinced by the government and related policy elites that the choice is not just necessary but also appropriate. This is facilitated by the construction of a discourse that projects a coherent vision of how the nation fits into an integrating Europe and a globalising world that also taps into deeper structures of national values and identity.

Such a legitimating discourse is especially important because the push for change comes not from the bottom up, that is, from popularly expressed support for global and European-induced change, but rather from the top down, from modernising governmental as well as business elites intent on promoting national economic and institutional changes as the only solution to domestic as well as European and global economic and political problems. Moreover, because such changes in many cases strike at the very core of national values and identity with regard to traditional understandings of economic organisation, social welfare, and even political democracy, the elites responsible for instigating such change seek to come up with a public discourse capable of redefining those core values and understandings in keeping with the new realities.

Any such discourse will of necessity be quite different from one European Member State to the next, given the fact that Member States start from very different economic, institutional and ideational specificities, have responded to global and European pressures differently, and have, therefore, come up with different kinds of public discourses constructed by different mixes of elites. Moreover, just as some countries have changed more in response to European and global pressures than others, and some have managed change more successfully than others, so some have been more successful than others in constructing a legitimating discourse. Among the three major European countries, this comes out most clearly: France remains in search of a discourse capable of accounting for its significant Europe-related economic and institutional changes; Britain is in the process of renewing a discourse which has, since Thatcher, served to account for changes related more to globalisation than Europeanisation; and Germany is in the midst of recasting its post-war discourse in response to comparatively recent economic and institutional changes related to globalisation and Europeanisation (see Schmidt 1997a; Schmidt n/a).

The article begins with a focus on the theoretical arguments related first to the nature of discourse, by defining its parameters, outlining its functions, and elucidating the standards by which it can be evaluated. Throughout this first part, the article seeks to illustrate the theoretical insights through empirical discussions of the post-war construction of discourses in France, Britain and Germany (for more detail, see Schmidt $\mathrm{n} / \mathrm{a}$ ). The second part considers how the discourses have responded to the challenges to traditional conceptions of economic organisation, social welfare and 
political organisation from European and globally-related economic and institutional change.

\section{The Nature of Discourse}

Whatever success European governments may have had in adjusting to global and European economic pressures or to European institutional pressures, this may prove empty if they cannot concomitantly gain acceptance of the economic and institutional changes. And this is where national discourse plays a crucial role. Discourse does this in four ways along two dimensions: ideationally, by presenting a policy programme that is conceptually sound (cognitive function) and that resonates with national values (normative function); and interactively, by serving policy elites as the basis for constructing a policy programme (co-ordinative function) and for persuading the larger public as to its merits (communicative function).

\section{The Ideational Dimension of Discourse: Cognitive and Normative Functions}

As the representation of a set of ideas, public discourse can be very broadly defined as the sum of political actors' public accounts of the polity's purposes, goals and ideals which serve to explain political events, to justify political actions, to develop political identities, to reshape and/or reinterpret political history, and, all in all, to frame the national political discussion. This is essentially the definition of political theorists such as March and Olsen, who see discourse as a central part of democratic governance, involved in helping to consolidate the political identities of citizen and groups; to define appropriate political action; to interpret and control political events; and to 'define the meaning of history, the options available, and the possibilities for action' (March and Olsen 1995, pp. 46, 62; see also Reich 1988). My use of the term, however, is somewhat narrower, since I focus primarily on the discourse of policy elites within a given issues area or policy arena (here political economy, but one could do the same for defence, citizenship, energy, and so on), as opposed to any more general public discussion within or across issues areas. As such, my focus is similar to that of the 'policy narratives' that follow from the work of Michel Foucault, Roland Barthes, and others (see, for example, Larat 1999; Roe 1994; Gottweis 1999; Radaelli n/a) — although I make no claim to this literature's philosophical presuppositions.

My definition of discourse also shares with Rein and Schön the assumption that discourse serves to 'frame' a complex reality by providing 'guideposts for knowing, analyzing, persuading, and acting,' But my definition does not go as far as they do to claim that discourse is inseparable from the 'underlying structures of belief, perception, and appreciation' on which policy positions rest (Rein and Schön 1991, pp. 263, 289; Schön and Rein 1994, p. 22). Rather, my definition of discourse considers the underlying structures of beliefs, or values, as separate, as in the discourse but not of it. Similarly, although my notion of discourse bears a striking resemblance to the 'référentiel' developed by French policy analysts such as Bruno Jobert (1992) and Pierre Muller (1995), which focuses on the 'ideas in action' through which social groups (re)construct visions of the world which allow them to (re)situate themselves in the world, I draw a greater analytical distinction between policy programme and discourse. By considering discourse on its own, apart from the policy programme it promotes and from the values to which it appeals, I seek to take account of the ways in

(C) Blackwell Publishers Ltd. 2000 
which discourse connects with (or is disconnected from) a given policy programme and the ways in which discourse may affect values rather than simply reflect them.

In my definition, discourse performs a cognitive function by providing convincing arguments in favour of a given policy programme, demonstrating why it is better than past policy programmes in providing effective solutions to current problems and to anticipate, and thereby avoid, future problems. And it serves a normative function by legitimating the policy programme through appeal to national values, generally by showing how the policies build on long-standing values and on deep-seated structures of national identity while creating something new, better suited to the new politicoeconomic realities. Although these two functions are analytically distinguishable, they are not easily separable empirically.

As part of its cognitive function, the discourse first and foremost sketches out the overall outlines of a policy programme that can serve as a guide to action, by identifying the issues to be addressed, problems to be solved, goals to be attained, and policy instruments to be used. The policy 'paradigm' contained in the discourse, much like the classical definition of a paradigm in science (Kuhn 1970), need not be an elaborated structure, but instead have great potential for further elaboration. Much like Lakatos' (1970) research programmes, such policy paradigms or programmes have a 'core'-made up of the most basic principles, goals, assumptions about appropriate courses of action, and methods of translating general principles into action-which is likely to change very slowly compared with its 'periphery' of policy applications (see Majone 1989). The periphery can be conceived of as representing policy sectors for which the dominant paradigm serves as a guide to action, and which develop their own sectoral discourses for which the dominant discourse serves as a template. $^{2}$

Thus, discourse provides a central or basic idea that is generally rich enough in content to provide the basis for policy-makers to come up with solutions to a wide variety of policy problems, many of which may not have been anticipated in the initial policy programme. In addition to such 'heuristic' content, ${ }^{3}$ the discourse offers arguments in support of the policy 'paradigm' that for the most part meet certain generally accepted cognitive standards, i.e. relevance, by accurately identifying the problems the polity needs or expects to be solved; applicability, by showing how it will solve the problems it identifies; and coherence, by providing reasonably consistent arguments that apply without major contradiction to a wide range of problems. ${ }^{4}$ Finally, it must also situate itself in relation to other discourses, whether a dominant discourse or rival discourses competing for dominance, by showing how it can solve

\footnotetext{
2 Another way of describing this distinction is that of Herbert Gottweis, who differentiates between 'political metanarratives' and 'policy narratives,' where metanarratives provide an overall conceptual framework that establish the collective political identity within which the more specific policy narratives proceed (see Gottweis 1999).

3 This sense of 'heuristic' content is borrowed from the philosopher of science, Imre Lakatos (1970), who has this as a requirement for research programmes, although others also expect it without using the word, whether Kuhn (1970) for paradigms or Karl Popper (1961) for falsifiable explanations.

${ }^{4}$ These standards are not far from the basic standards that logical empiricists originally identified as necessary for explanation: logical consistency, empirical verifiability, and explanatory relevance (cf. Hempel 1965). The main difference here is that in place of empirical verifiability, I have put applicability, in keeping with subsequent approaches in the philosophy of science (e.g. Kuhn 1970; Lakatos 1970), which substituted a success standard for a truth standard. I have also substituted the word coherence for consistency, to emphasise the importance of the policy argument forming a consistent whole while allowing, however, for some contradiction. For further discussion of the standards, see Schmidt 1986.
} 
problems the previous policy paradigm could not, while anticipating, and avoiding, future problems. ${ }^{5}$

Much of the political science literature that uses the language of 'paradigm' to explicate politics and policy-making tends to concentrate on this cognitive function (e.g. Hall 1993; Surel 1995). But in gaining or retaining acceptance for a policy programme, the discourse cannot rely on its cognitive function alone. It also performs a normative function, by providing persuasive arguments that show how a policy programme serves to build on long-standing values and identity while creating something new, better suited to the new realities and more appropriate than the old 'public philosophy' (Campbell 1998). Unlike in science, where the problems stem almost entirely from the science-related concerns of scientists and the solutions are certified as such by scientists alone, in society, as most philosophers of science themselves acknowledge, the problems stem from the societal concerns of the citizens while the solutions are recognised as solutions only if they are accepted as such by the citizens as well as by policy-makers (Schmidt 1988). In consequence, the ideational task of a discourse is dual: (1) to provide cognitive arguments capable of satisfying policy-makers as to the robustness of the solutions provided by the policy programme; and (2) to provide normative arguments capable of satisfying policy-makers and citizens alike that those solutions respond to the real problems of the polity in ways that serve its underlying values.

Normative justification, however, does not entail that all policy programmes promoted by a discourse simply conform to pre-existing national economic, social and political values. Much to the contrary, since any new discourse that proffers a real shift in policy preferences generally also promotes the transformation of national values by reinterpreting traditional conceptions of economic organisation, social welfare, or even political democracy in a publicly acceptable, or at least 'sellable' way (putting great burdens on the coordinative and communicative functions, as we shall see below). National values, after all, are themselves generally 'contested and contingent,' changing over time as conditions and attitudes change (Katzenstein 1996, pp. 2-3). And it is the role of discourse to give expression to these value changes as it promotes them.

How, then, does such a discursive transformation in values work? Here, the history of ideas can prove helpful. For a new idea or, in the terms of Quentin Skinner (1988), a major text to have been accepted as such, it will have provided a new conceptual framework that successfully responded to a legitimation crisis in political society by rewriting the old political conventions or ideology and recharacterising political action. In other words, a new discourse which has such an idea or 'text' at its foundation has succeeded because it has provided a new understanding of present policies with new prescriptions for the future that builds on past values as it rewrites them, often by taking shards of past communal memories and understandings and reweaving them into something new and different which nevertheless continues to resonate with the population.

The change in discourse, then, reflects something of a revolution in world-view for a polity, since it demands a shift not only in policy paradigm but also in the underlying values of the polity as a whole. Such a shift is not, however, the same as a Kuhnian 'revolution' in scientific 'paradigm,' and to talk of a revolutionary change in discourse and its policy 'paradigm' is admittedly rather problematic in epistemological terms.

\footnotetext{
${ }^{5}$ This is the success standard typically used by Lakatos (1970) as part of 'methodological falsification.'
} 
The danger with attaching the language of paradigm to discourse is that it makes all change appear revolutionary in the sense of engendering a radical break from the past without the possibility of understanding that past, given the new interpretation of the present, or without the ability to compare 'facts' across paradigms (Schmidt 1987). But this is not the case in society, even if it may be the case in science, since the understanding of past ideas and values is always possible even if those ideas and values are not shared in the present, whether by setting them into the ideational context of the past (Skinner 1988) or by tracing their progressive changes into the present (Pocock 1964). And although the 'facts' they evoke may be different, the data brought in evidence can be compared. Moreover, in the transition from one discourse to the next, the old ideas and values are contained in the new discourse, as it seeks to demonstrate that the new ideas are cognitively better than the old, and that the new values are really the same old ones reinvigorated, or even older societal values that had been forgotten but deserve resurrection, albeit in a new and different way (on this, see Dryzek and Leonard 1988).

More simply put, revolutionary change in policy paradigms ensures that while a policy programme may be new, the values that serve to justify them normatively are never more than renewed and the data on which they rely can be cognitively evaluated. Thus, for example, at the same time that Prime Minister Thatcher claimed to be making a revolutionary break with the recent history of state interventionism and collectivism, she justified her policy prescriptions in terms of the country's longstanding adherence to liberal economic principles and their basis in deep-seated British values favouring individualism (Schmidt 2000). Moreover, she also advocated a coherent policy programme based in a monetarist paradigm that could be (and was favourably) contrasted with Heath's earlier failed return to Keynesianism (Hall 1993).

Changes in discourse, however, need not always be revolutionary. Evolutionary change is also possible. One can talk of a renewal of the discourse where the policy changes are not major, and where the discourse may claim to solve old concerns or new problems without radically changing the policy orientation or policy instruments of the original policy paradigm. A case in point is Blair's discourse of the 'third way,' which purports to fulfil old Labour party aspirations through new Thatcherite methods, and which, while still neo-liberal in its appeal to individualism, nevertheless also taps into deep-seated collectivist values about compassion, equality (at least of opportunity), and social justice (Schmidt 2000). In another vein, although Blair's discourse remains as pro-global as Thatcher's, globalisation, instead of representing one component in an ideologically driven reform effort, represents the driver of neoliberal reform (Hay and Watson 1998; Schmidt n/a)

One might better talk of a recasting of the discourse and its policy paradigm where new policies make seemingly radical change in the policy programme, whether in policy orientation or policy instruments, thus altering the practice while leaving the conceptualisation present in the discourse largely intact. This appears to be the case in Germany today where, rather than abandoning the traditional liberal social-democratic discourse, governments have attempted to recast it, by emphasising the liberal and de-emphasising the social in the liberal social-democratic discourse. They have not, however, had much success in this, even under Schröder who, after trying out Blair's 'third way' in the summer of 1999 and Jospin's more socialist discourse later in the autumn, fell back into the more traditional discourse by the end of the year, while still trying to institute neo-liberal reform (Schmidt 2000).

But whether new, renewed, or recast, changes in discourse generally occur only in 
times of crisis, generated most often by the perceived inability of the old 'policy paradigm' to solve the political, economic, and/or social problems of the moment. Events, in other words, are key to creating a receptive environment for a new set of ideas (Hirschman 1989). The economic crisis in the mid to late 1970s was one such set of events, and led to the introduction of new policy paradigms in a number of countries, most notably with the move to neo-liberalism in Thatcher's Britain.

The search for a replacement for the old policy paradigm, however, need not always bring in an entirely new, unfamiliar discourse. For although there is normally (that is, during periods of Kuhnian 'normal science') only one dominant paradigm and legitimating discourse in the polity, there are often other, minority discourses in the polity which propose alternative paradigms, waiting in the wings, hoping one day to become dominant. In the mid to late 1970s, both Britain and France clearly experienced an economic crisis which led to a demand for an alternative policy programme. But while Britain came up with a new discourse and programme, Thatcherite neo-liberalism, which propounded greater laissez-faire capitalism and the rollback of the state in place of Labour's neo-Keynesianism and state interventionism, France first sought to replace the faded Gaullist paradigm with a discourse and programme that had been in development throughout the post-war period, namely, the socialist discourse of a break with capitalism and greater state interventionism. It was only after this discourse was abandoned, along with its policy paradigm, that a new, neo-liberal discourse akin to the Thatcherite came to the fore; but this too was short-lived (Schmidt 1996).

Political crisis does not always generate a demand for a new, renewed, or even recast discourse, however. If a discourse is supple enough, it can respond to a crisis in the polity without suffering itself from crisis. But this depends upon whether it can generate policy responses that are consistent with its overall policy programme and are justifiable in terms of the underlying policy values it promotes. In Germany, the postwar liberal social-democratic discourse survived the economic crises of the 1970s intact, in large measure because its stability-based philosophy of the social market economy was supple enough to rally support for policies that promoted austeritysomething that the French conservative discourse (under Giscard), given a growthoriented economic philosophy and political commitments to fighting unemployment, could not sufficiently justify and that the French socialist discourse (under Mitterrand from 1981 to 1983) which proposed neo-Keynesian expansionism chose to reject.

For the success of a discourse in times of crisis, in fact, a lot depends upon how coherent it is across related policy issues or, put another way, how well it can deal with the inevitable contradictions in cognitive and/or normative aspects of the discourse. The problem with coherence has to do with the fact that while the overall 'master' discourse tends to set out a wide and often vague set of principles, it is elaborated in a variety of different sectoral discourses which, depending upon the problems of the sector (to say nothing, right now, of the powers of interests or the constraints of institutions), may fit more or less well with the master discourse. ${ }^{6}$ Typically, at least one sector remains exceptional. In most European countries, this has been true of agriculture with regard to the political economic discourse (it fits perfectly, however, within the context of most countries' social welfare discourses and policy paradigms). ${ }^{7}$ In other cases, moreover, residues of earlier policies and their discursive justification

\footnotetext{
${ }^{6}$ My thanks to Wolfgang Streeck for suggesting the idea of master vs. sectoral discourses.

${ }^{7}$ My thanks to Beate Kohler-Koch for this caveat.
} 
contaminate the newer discourse in the sector. These 'anomalies' are generally minor, however, so long as they occur in a small number of sectoral discourses.

Much more problematic for the discourse is when the general cognitive arguments seem to contradict one another, or conflict with the normative. Most typical is when macro-economic programmes that institute budgetary austerity butt up against pledges to maintain expansive socio-economic programmes, or when cutbacks in the socio-economic arena offend deep-seated notions of social justice and equality. This has largely been the case in French discourse, at least up until Jospin, which has had both a cognitive problem stemming from the logical contradiction between its neoliberal policies of economic belt-tightening and its expressed support for continued high levels of social services, and a normative problem with regard to its inability to reconcile its economic policies with its commitment to 'social solidarity.' This is in contrast to discourses where the cognitive and normative arguments mutually reinforce one another, as when a discourse that promotes both neo-liberal macroeconomics and social welfare cuts can appeal for legitimation to national values of individualism, as was the case in Thatcherite Britain (Schmidt 2000).

The most coherent of discourses are likely to be those based on one or another ideology, such that the policy 'paradigm' is something akin to an ideological system, or a relatively closed system of ideas. When an ideology provides the grounding for a discourse, the discourse can appear particularly powerful because it necessarily offers a coherent vision and clear policy prescriptions. And, as long as the discourse has accurately predicted the potential impact of those policy prescriptions and has sufficiently justified them in terms of renewed national norms and values, the discourse is likely to be particularly successful. Thatcher's ideologically-grounded neo-liberalism, for example, met these criteria so successfully that it has become the discourse of the opposition as well, so much so that Labour's electoral victory can be attributed in large measure to Blair's embrace of the discourse. If, however, the ideologically-based discourse fails to predict accurately the effects of its policy programme and/or cannot justify the differing outcome in terms of the discourse, then the very coherence of the discourse is likely to cause it major trouble, and possibly spell its demise. Mitterrand's ideologically-grounded socialism of 1981 to 1983, with its neo-Keynesian macro-economic policies, its expansionist micro-economic policies, and its generous socio-economic policies, was abandoned because within the context of the ideology it could not cognitively account for the failure of the policies to promote growth or normatively justify the subsequent turn to budgetary austerity in terms of its social commitments.

Discourse, however, need not be based on ideology. In its absence, the discourse can evoke the future, as the French socialists' emphasis on modernisation in their successful 1988 election campaign, or on maintaining past accomplishments, as the Kohl government did in its failed election campaign of 1998. What such discourse loses in the power of its coherence, it gains in greater flexibility to promote policies that are less closely aligned with previous ones, as long as they fit the overall policy programme and are normatively justifiable in terms of the values promoted by the discourse.

The main ideational test of a discourse, then, involves its ability to provide a reasonably coherent policy programme that offers solutions to a wide range of current and future problems and that is legitimated by reference to reinterpreted economic, social, and political values. And any discourse that does not pass the test-whether on the cognitive side because its programme does not accurately represent the problems to 
be solved or provide adequate solutions to those problems, or on the normative side because it does not concern itself with the impact of its solutions on national valueswill have difficulty in succeeding. For if, on the one hand, the discourse does not offer a reasonable representation of reality, either of the problems or its solutions, then the discourse cannot appropriately inform or orient the public, by giving it a clear vision of where its policy programme is taking the country. And if, on the other hand, it does not resonate with national values, then the discourse cannot legitimate the policy programme to the public, by making it clear why the direction in which the policy programme is taking the country is appropriate. And either way, the discourse is not likely to be successful.

But this suggests that success for a discourse depends upon more than just its ability to meet cognitive and normative standards which are internal to the ideational dimension. In fact, success is also related to the ability of a discourse to gain and maintain a constituency first among policy elites and then among the public at large. Good ideas alone, in other words, are not enough. They must be translated into a common language accessible to the larger public that can serve as the basis for a discourse capable of convincing citizens of the appropriateness and legitimacy of change.

\section{The Interactive Dimension of Discourse}

In its interactive dimension, the discourse serves a coordinative function by providing a common language and ideational framework through which key policy groups seek to come to agreement about a policy paradigm and a communicative function by serving as the vehicle through which policy elites seek to persuade the public that the policy paradigm is necessary and appropriate. These coordinative and communicative functions of discourse are generally both analytically and empirically separable, even though they are not always distinguishable from one another at the margins. This is because policy elites tend to be involved both in coordinating the construction and development of the policy programme amongst themselves at the same time that they are also generally involved in communicating it to the larger public. The separation of the coordinative and communicative stages of discourse is also evident in the scholarly literature, which tends to divide between those interested in the communities responsible for the generation and implementation of policy ideas and those more concerned with the communication of those ideas to the larger public.

This account of discourse draws on both literatures. My discussion of the coordinative stage of discourse builds on the extensive literature concerned with the 'epistemic communities' and 'advocacy' or 'discourse' coalitions (e.g. Haas 1992; Sabatier and Jenkins-Smith 1993; Wittrock, Wagner and Wollmann 1991; Muller 1995) where the groups at the centre of policy construction tend to come up with the ideas and meanings that form the bases for collective action and identity. My discussion of the communicative stage, by considering how policy elites persuade the public of the validity of the policy programmes they constructed, joins with Peter Hall's notion of 'national political discourses' (1989, p. 383f) and Gerhard Lehmbruch's 'discourse coalitions' (1999), although the focus of Lehmbruch's inquiry is primarily on the ideational rather than the interactive dimension, that is, on the ideas and not on how a policy programme is constructed and communicated. Finally, although like Jürgen Habermas (1996) I, too, am interested in the relationship of 'communicative action' to democracy, Habermas' notion of discursive democracy, by 
focusing on the normative requirements of a non-coercive public discourse that would ensure an ideal democratic state, is more prescriptive than it is descriptive of the empirical role of discourse in contemporary democracy, which is my purpose here.

\section{The Coordinative Function of Discourse}

Any discourse, whether new or ongoing, generally performs a coordinating function by providing the frame within which policies can be elaborated and justified by the key policy elites involved in the construction of the policy programme. The frame provided by the discourse generally offers a common language through which the different groups crucial to the policy process can talk to one another and a common vision in terms of which they can iron out their differences. In some countries, in particular those where power is concentrated in the executive, the coordinative discourse tends to be dominated by a restricted, government-centred policy elite, whether a politicotechnocratic elite (as in France) or a political party elite (as in Britain). By contrast, in countries where power tends to be dispersed, a much wider cross-section of policy elites tends to be involved in the construction of the policy programme, encompassing not only governmental political and technocratic elites but opposition parties and interest group leaders, in particular those from business and labour (as in Germany and the smaller consociational democracies like Switzerland, Austria and the Netherlands). ${ }^{8}$

Although government officials tend to be central to the construction of a discourse, the ideas informing the discourse need not come primarily from government actors, whether politicians or civil servants, but may instead be the product of policy experts, academics, the press, interest group leaders, and even social movements. ${ }^{9}$ Thus, they may be generated by 'epistemic communities' (Haas 1992) which elaborate the ideas that make up the core of the sectoral policy programme; 'advocacy coalitions' (Sabatier 1993) which create 'policy subsystems' within any given policy sector; 'discourse coalitions' (Wittrock, Wagner and Wollmann 1991; Lehmbruch 1999) that 'aggregate people from a variety of positions who share a particular belief system and who show a non-trivial degree of co-ordinated activity over time' (Singer 1990, p. 440; see also Lehmbruch 1999); or the 'médiateur' or interlocutor who constructs and conveys the 'référentiel,' or new frame of reference (Muller 1995). At the national level, these groups or communities can exercise great power in fleshing out the content of a policy programme or even in promoting a particular discourse and policy programme, thereby enhancing their own power, if not acquiring formal power (Hall 1993, p. 290).

It is in this context, moreover, that the EU can be considered to contain epistemic communities (Mazey and Richardson 1996; Kohler-Koch 1998, pp. 99-101) or advocacy coalitions (Sabatier 1998) which have generated a set of policy preferences

\footnotetext{
${ }^{8}$ In countries where a small governmental elite dominates the construction of the policy programme, as in France and Britain, the coordinative discourse may be quite thin by comparison to the communicative, which is focused on winning over the larger public. In countries where a wider cross-section of policy elites is involved in policy construction, the coordinative discourse tends to be more elaborate, since actors' energies are focused on agreeing amongst themselves and reporting back to their own constituencies, while the communicative discourse may end up quite thin, often as little more than a government announcement of compromise. I do not elaborate on this theme here, but for more detail, see Schmidt (n/a; 2000)

${ }^{9}$ Lehmbruch (1999) shows the importance of academics in Germany; Hall (1993) emphasises the role of the financial press in Britain.
} 
with regard to European integration that have become part of national discourses as a result of the overlap of European epistemic communities with national ones, and of the substitution of European policies for national ones. This has especially been the case in such areas as competition policy, agriculture and central banking, where the ties between European and national policy-makers are particularly close, and where the national level policies are most tightly linked to the European. But even European policy ideas, propounded by European policy elites or epistemic communities that are, in fact, made up of nationals of European Member States, cannot be directly imported into the national context, but are translated into national terms even as the policies they support are transposed into national legal structures.

When ideas come from outside, whether from the influence of European ideas and elites on national policy-makers, from global ideas and elites, or from the ideas and elites of another culture, they can be understood only in the terms of the culture into which they come (Hall 1989). Thus, the pressures from globalisation and European integration that seem to demand convergent economic and institutional reforms result in divergence not simply because of the limits set by the economic circumstances or institutional context but, even prior to this, by the limits of the imagination. Culturally and historically specific conceptions colour the manner in which new ways of doing and thinking are adopted and adapted to the political context, and set the limits to the transferability of new ideas (Katzenstein 1996). Thatcher's neo-liberalism worked in Britain because it resonated in a culture that has traditionally valued a limited state and liberal economic principles. But this could not be transposed 'as is' to France, given the continuing importance of the role of the state in the political imagination (Schmidt 1996, Chapter 5). Such neo-liberalism, however, could not work even in America, despite the ideological affinities between Thatcherism and Reaganism, because there the decentralised institutions preclude the kind of neo-liberal interventionism that Thatcher could engage in. Thus, while cultures may make policy elites blind to the possibilities of new ideas, institutions may limit their receptivity (see Héritier, Knill and Mingers 1996) or their 'administrative viability' (Hall 1989, pp. 373-375).

Interests also matter, since these can derail even the most strongly supported sets of ideas even if the institutions are receptive and the culture compatible. And no amount of discourse will succeed in promoting a new policy paradigm where it does not address the interests of societal groups, in particular powerful groups. This could simply mean giving voice to such interests. But more likely it also means attempting to overcome entrenched interests, by altering perceptions of interest not only cognitively, by arguing that change is necessary and in the best (material) interests of all, but also normatively, by arguing that change is in the public interest (or common good) and therefore the appropriate thing to do. This worked in the case of Thatcher's neo-liberal programme and initially for the Socialists' neo-Keynesian expansionism in France. But, as noted above, once the policy programme did not deliver what it promised, proving to be neither in the best economic interests of the country nor in the political interests of the government, the Socialists abandoned the discourse along with the policy programme.

In constructing any policy programme, in short, policy elites confront entrenched interests, institutional obstacles, and cultural blinders to change. Their ability to overcome these depends not only on the cognitive and normative merits of their policy programme but also on their ability to communicate these to the general public. 


\section{The Communicative Function of Discourse}

It is one thing to coordinate the construction of a discourse by building agreement on a policy programme among policy actors central to the policy-making process, and another to communicate it successfully to the public at large, which is the essential criterion for a successful shift in policy paradigm. And for this, one needs politicians who, as individuals who win elections in democracies primarily on the basis of their communicative skills, are in the business of marketing the discourse that will guarantee them not just election but re-election. ${ }^{10}$ It is often in the electoral process that politicians present the central ideas and underlying values of the policy programme in a manner accessible to the media and the larger public, providing the public with both a new frame of reference within which they can understand and interpret events, and a clear picture of what can be done. ${ }^{11}$ From the point of view of the public, this communicative aspect of the discourse responds to its need for a sense of orientation with regard to the country's present and future and for a sense of legitimacy with regard to government policy.

This public communication by political leaders is where the overall outlines of the policy programme may be most clearly articulated, where the 'master' discourse is given expression by the 'master' politician, that is, by the president or prime minister once elected, and the sectoral discourses, by the other members of government. This is also where the coherence of a discourse may be most clearly seen, since politicians' pronouncements can enhance or diminish the appearance of coherence. And the more coherent the government's communicative discourse, and the clearer the picture it provides to the public, the more likely the public will see events from that point of view (Zaller 1992, pp. 8-9). However, whether the party in power can present a single image to the public depends upon many things, not only on the coherence of the ideas but also, equally importantly, on its control over its own members, whether in government or in parliament (something Blair in Britain has been intent on ensuring, and which Schröder in Germany could not manage in his first year in office). This says nothing, of course, about whether a government can get its policy programme through, which may also have to do with the structure of political organisation and of state-society relations.

The success of a new discourse, then, is predicated upon its ability to offer arguments that convince not only policy-makers but also the public. But this is not always possible, since however good the arguments, the public may weary of the discourse while waiting for the policy programme to deliver the promised pay-offs (as in the benefits of Economic and Monetary Union). In this case, the success of a policy programme may be ensured by public attention being distracted for a time by other kinds of discourse that focus on other kinds of issues of popular import (e.g. military, moral, cultural). Sometimes, these come up conveniently to save a politico-economic discourse and policy programme in trouble, ensuring re-election for a government that might have lost on the basis of public perceptions of its performance at that particular juncture. In Britain, for example, Thatcher's neo-liberal economic discourse was

${ }^{10}$ Because of the law of anticipated reaction or the notion of the 'fleet in being,' politicians adopt discourses that are constructed in such a way as to be normatively and not just cognitively acceptable, and therefore to be potential national discourses rather than simply the ideas of a technocratic or academic elite (Scharpf 1997).

${ }^{11}$ On how political elites influence the public, see, for example, Zaller (1992); Mutz, Sniderman and Brody (1996). 
eclipsed for a while in the aftermath of the Falklands War by her more militaristic incantations of past British military glory and memories of Empire, which helped usher the Tories back into office despite public disenchantment at the time with the policies linked to the politico-economic discourse. The relationship between a discourse and elections, in other words, is contingent. Such a wide range of factors could explain winning (or losing) elections, that politicians' discourse can naturally only be one piece in a very large and complex puzzle.

The relationship between discourse and policy change is much closer, since the discourse serves as the language and framework through which policy elites construct a policy programme and with which the public can reconceive of policies - even if they may not accept them. Here, too, however, so much goes into policy change or lack thereof, including the configuration of interests and power, the institutional arrangements, cultural patterns, events, and so forth, that there can be no causal relationship between discourse and policy change. ${ }^{12}$ At best, we can talk of discourse 'enabling' policy change (Diez 1999). The need to communicate with the public is nonetheless central to the survival not only of the policy programme supported by the discourse but also of the politicians who depend for re-election at least in part on the public acceptance of that programme. Although policy change can be imposed even without discourse (and sometimes is), the legitimating aspects of discourse are generally necessary to the policy programme's long-term acceptance.

At this communicative stage, moreover, there is also an interactive element. It is not just policy elites telling the public what the policy programme is all about, but also listening, and adjusting the programme where necessary in response to public opinion. To ensure public acceptance, the policy programme promoted by government through its communicative discourse generally becomes the subject of a broader policy discussion in society generally engaged in by the 'policy forums' that serve as the institutional vehicles for debates on public policy issues (Rein and Schön 1991), that is, by opinion leaders from outside government as much as from inside, including the media, corporate executives, opposition parties, labour leaders, policy experts in universities and think-tanks, heads of major interest groups, party activists, members of (public) interest organisations, civic action groups, social movements, churches, and so forth. And it is also made publicly accessible through open meetings, newspaper articles, election campaigns, the internet, and so on. This is where policy programmes and/or their sectoral applications developed generally outside of public view in the 'closed debates' among policy elites, experts, and 'attentive publics' are put to the test in the 'open debates' that take place in the public sphere when an issue has gained public attention (Guiraudon 1997). And here, too, therefore, the policy programme as much as the discourse may be modified in response to the reactions of this 'public of organised private persons,' or the 'bourgeois public sphere' (Habermas 1989).

Such public discussion ensures not just the widest possible dissemination of information about the policy programme but, even more importantly, the widest possible debate about it. Any monopolistic control or monolithic approach is problematic, since critical stances are often helpful in clarifying the issues and even modifying positions (March and Olsen 1995, pp. 82-83). Criticism, as long as it brings

${ }^{12}$ In certain cases, communicative discourse may even hinder policy change, as in the case of the rights of immigrants, where Guiraudon (1997) found that immigrant rights were extended primarily in the context of 'closed debates,' or a coordinative discourse, because whenever the debate spilled over into the public sphere, the discussion became highly politicised and reduced the chances of positive reform. 
reasoned responses from the policy elites responsible for the discourse, may be vital to ensuring the legitimacy of the discourse and the viability of the policy paradigm. Moreover, the lack of criticism does not necessarily signal acceptance or agreement, it merely hides disagreement and makes it more difficult for government to gain a sense of the fault lines. And the more general the discussion, the more likely that what starts out as government commitment can become a national conviction, and even accepted as part of 'public truth' (Habermas 1992).

'Public truth,' of course, is something different from the discourse, which need not always be truthful (if policy-makers know that their policy prescriptions are shaky) or generally accepted (which often takes time). Public truth is the outcome of the discussions and debates among all the various communities, agencies, and so forth, and underlies the 'interpretive communities' within which Habermas (1992, p. 449) sees mutual understanding emerge. Public truth, in other words, is more basic to a polity than the discourse, but it has significant bearing on it. For the greater the distance between public truth and public discourse, the greater the difficulty of convincing the public of the value of the policies that the discourse favours, and the greater the risk of public disaffection. This had been the problem for the Juppé government, given its claims to be able to solve the problems of unemployment and social welfare while at the same time continuing to meet the Maastricht criteria. And although this remains something of a problem for the Jospin government, it has been lessened by the government's seemingly persuasive communicative discourse (judging from the Prime Minister's popularity) that it is possible to balance the needs of efficiency with a commitment to social equity (Schmidt 2000).

For a public discourse to succeed, then, it is better if it is widely debated, openly constructed, and generally accepted as true. This is as much the case for a new discourse seeking radically to change the old 'policy paradigm' as for an ongoing discourse seeking to accommodate change through the accepted policy paradigm. In other words, whether change in discourse is revolutionary or evolutionary, communication is of the essence, even if this means that there may be a time lag due to the need for governments to change their ongoing commitments, to negotiate change with societal groups, or to convince the broader climate of opinion (Hall 1993, p. 279).

Communication is key not simply to the marketing of a discourse, however, but to the maintenance of democracy. Discourse is one of the essential elements of democratic politics, helping to hold a democracy together by giving the population a sense of joint purpose and meaning, to counter narrow self-interest in favour of a more common interest, to support long-standing interests, institutions and culture or to undermine them. Moreover, politicians' pursuit of public acceptance of a policy programme through discourse is at the very foundations of representative democracy, with elections being most often the way to consecrate a discourse or bury it. Whatever the intellectual commitments of the policy elite, in a democracy they must be able to communicate these successfully to the larger public as they coordinate the elaboration and implementation of the policies with relevant policy players. But there is nothing inevitable about discourse. Although there is always discourse, nations at any given time may have better or worse discourses, meaning that some may be better able than others to provide legitimation for political change or continuity. But failures in communication can have dire consequences for democracy. 


\section{The Challenges to Democratic Discourse from Globalisation and European Integration}

The risks to democracy are especially great for European countries, which have undergone tremendous change in response to the twin challenges of globalisation and European integration. These risks stem primarily from the fact that the economic and institutional changes instigated by globalisation and European integration have struck at the very foundations of European Member States' self-conceptions. Such changes challenge popular expectations about the role of the state, throw open for question traditional conceptions of economic organisation, social justice and political democracy, and, thereby, also jeopardise the deeper structures of national values and identity which are often attached to such traditional conceptions. ${ }^{13}$ The task of democratic legitimation for governing elites in all Member States is a difficult one, then, since their public discourse must not only explain why the economic and political changes are necessary but also how they may be appropriate. And this has been more difficult for some countries than others, depending upon the amount of change required and the ability of elites to come up with legitimating discourses.

\section{The Challenges to Traditional Discourses about Economic Organisation}

In the economic sphere, European integration has promoted macro-economic convergence through the pursuit of economic and monetary union (EMU) and micro-economic liberalisation through the establishment of the Single Market. For some countries, this has demanded more change in their economic policies and economic management systems than others, given requirements such as an independent central bank, independent regulatory agencies in deregulated sectors, an end to many forms of state aid and industrial policies, and so on. Moreover, whatever the adjustment requirements, the creation of an independent European Central Bank, the negotiation of common European standards, the deregulation of traditionally highly-regulated sectors, and so forth have generally diminished traditional national governmental autonomy in decision-making and control over economic actors.

Such changes necessarily challenge commonly-held, nationally specific discourses about the appropriate organisation of the economy and the role of the state within it. Thus, they alter expectations about how government should manage the economy, for example, whether it should have an independent central banking authority focused on damping inflation - the German preference which has become the European standard; a government-controlled central bank maintaining stability-closer to the traditional British view; or a government controlled central bank and banking system promoting growth - the French practice until the early 1980s. Similarly, they alter expectations about how government should interact with business, that is, whether it should be directive, through an interventionist state, as in France until recently; cooperative with an 'enabling' state, as it remains for the moment in Germany; or more 'hands-off' by way of a liberal state, as in Britain, which has become the European ideal.

${ }^{13}$ I am not talking here about the general constructions of nation-state identity, which political leaders have for the most part actively sought to reconstruct in their discussions of why to embrace globalisation or Europeanisation, but about the particular economic and institutional elements that contribute to the more complex entity that is national identity. On the relationship of Europeanisation to nation-state identity, see Risse (1998). 
For a country such as France, where national pride has been bound up with the glories of an interventionist state which saw its role as maintaining autonomous control over a national economy requiring protection from external economic forces, the challenge to the traditional discourse about the state's economic role has been significant. Since the early 1980s, the state has entirely altered its growth-oriented macro-economic management system to conform more with the German model and European ideal, and it has liberalised its directive micro-economic management system to become more like the British model and the European ideal. But French governments have been markedly unsuccessful in constructing a coherent discourse capable of legitimating these changes. Ever since the Socialists abandoned their socialist discourse in the early 1980s once they converted to liberal economic policies and the right failed to sustain their neo-liberal discourse of the mid-1980s in the face of electoral defeat (Schmidt 1996), French governments, for the lack of a better discourse, have managed little more than a pro-European and anti-global rhetoric which presented all of the changes related to European integration as necessary to protect the country economically against the incursions of globalisation (Schmidt n/a). But this did not help in the 1990s in the face not only of continuing high unemployment but also of Europe-led liberalisation which has challenged areas of the economy that lie at the very heart of French conceptions of state economic responsibility and the public interest. More specifically, deregulation and privatisation have been especially problematic in monopolistic areas traditionally seen as part of the 'service public' (e.g. post and telecommunications, energy, transportation), which has a special pride of place for the French both as a concrete example of the state's obligations to provide the citizen with essential services and as a symbol of the state's technical prowess (e.g. the minitel and Telecom, the TGV and the SNCF, the Concorde and Air France). Economic changes in these areas continue to be contested, with strong worker protest in response to threats of privatisation and deregulation, although somewhat less so under Jospin.

In Britain, the challenges with regard to traditional discourse about the state's economic role have been comparatively minor as yet, given a liberal state which has long conceived of its role as that of maintaining an open, global economy, and which has simply gone further in opening it up since the late 1970s. Moreover, Britain has undergone much less change resulting from European integration than France, given that liberalisation, deregulation and privatisation came ahead of the pressures from Europeanisation, and more in response to the pressures of globalisation and from the impetus of Thatcherite ideology. Even Britain, however, will have major problems if and when the country finally joins EMU, since this will mean having to justify relinquishing its symbol of national autonomy, the pound sterling, along with the macro-economic management autonomy it had retained with opt-outs from the EMU. And it has already had some difficulties reconciling its conception of a liberal state with the more interventionist European governance system, which Thatcher and Major sought to overcome through constant protest at any seeming incursions of European regulations, and Blair, more positively, through promises to lead Europe toward greater deregulation.

For Germany, finally, the traditional discourse about the organisation of the national economy has suffered the least until relatively recently. This is mainly because other countries converged on the German model in the macro-economic sphere while Germany itself was able to delay much micro-economic liberalisation until the 1990s. Germany was able to maintain its pro-global, pro-European discourse about the social 
market economy largely unchanged since its inception in the early post-war period (Schmidt n/a). However, with the ECB, EMU, and the common currency overshadowing the Bundesbank and bringing an end to the Deutschmark, the challenges to Germany's self-conceptions are potentially great, given that the German mark and the Bundesbank have been at the heart of Germany's post-war identity as an economically stable state - but only if these European institutions fail to promote stability in the way that the German institutions have traditionally done so. Moreover, although Germany's cooperatively managed economy has so far been able to accommodate liberalising reform, such accommodation may have reached its limits, given that EU regulatory requirements are already causing Germany to move toward more liberal forms of regulation and economic organisation without as much managed cooperation (e.g. in telecommunications). In this context, it is important to note that the pressures from European as well as global competition are also threatening the German model of managed capitalism, with big businesses and big banks adopting elements of market capitalism. In consequence of all of this, the post-war liberal socialdemocratic discourse of the social market economy, with its accompanying pro-global, pro-European rhetoric, may not be able to adapt as successfully as it has in the past to changing realities.

\section{The Challenges to Traditional Discourses about Social Welfare}

Equally importantly, the economic changes related to European integration also challenge post-war discourses about government's role with respect to social justice. This is because they are associated with the loss of government capacity in the socioeconomic arena, in particular with regard to the Maastricht criteria for monetary union that are seen to limit state ability to fund social assistance and to deal with unemployment. ${ }^{14}$ And where the state is no longer honouring what had been seen as long-standing obligations with respect to the disadvantaged, questions about national tenets of social justice that have held throughout the post-war period with the rise of the modern welfare state, if not longer, necessarily come to the fore. But again, the severity of the questioning, and therefore the need to convince the public of the appropriateness of cutbacks in the welfare state, depends upon whether countries hold deep-seated notions about the importance of individual responsibility (as in Britain) or about community obligation (as in France and Germany).

For France, the challenge to the traditional discourse about the state's obligations and citizens' rights by cutbacks in the welfare state has been particularly severe. This is because successive French governments have had great difficulty retreating from the generally-held commitments to 'social solidarity' that had become the watchword of the post-war period for the right as much as the left; the general understandings of the obligations of 'l'état républicain' that originated in the Third Republic; and the obsession with equality that goes back to the French Revolution (even if it has been honoured more in the breach). The failure of reform efforts (which were only seriously attempted beginning in the early 1990s) has much to do with the fact that French governments have been singularly unable to construct a legitimating discourse which

\footnotetext{
14 The loss of government capacity in the socio-economic arena is naturally much more complicated than this, and related to such things as changing demographics, and external economic pressures from increasing international competition in the capital and product markets. But in the internal political debates, Europe is often none the less seen as a primary factor.
} 
manages to reconcile economically-motivated welfare reform with deeply-held notions of social justice. Only with the Jospin government, which seems to have come up with a credible discourse about the need to balance economic efficiency with social equity, has welfare state retrenchment begun to make some real progress while avoiding the massive protests which came in response to previous governments' lame justifications or silence on proposed cutbacks (Schmidt 2000).

For Germany, the more recent beginnings of a rollback of the welfare state, although more symbolic than real, have been equally challenging to the traditional discourse about the state's obligations and citizens' rights. This is because citizens have come to expect a high level of benefits not only as a matter of state obligation, given that the country has had one of the most generous welfare states in the post-war period as well as a long history of 'social solidarity' dating back to Bismarck, but also as a matter of near property rights, given the earnings-related basis of social security. What is more, because the welfare system is tightly coupled with the rest of the economic management system - with post-war economic growth largely related to the post-war history of labour-management cooperation which produced informal incomes policies, solidaristic wage policies, and generous benefits for the core workforce-welfare retrenchment may also represent a further challenge to citizens' traditional conceptions of the appropriate organisation of the economy through managed cooperation. And because such reform must be negotiated among state, business, and union actors, success depends, at least in part, upon the reconceptualisation of those traditional notions of economic organisation as well as of the nature of social justice by those selfsame actors. So far, however, the government and social partners have yet to come up with a common discourse, let alone agreement on reforms, capable of reconciling the desire to liberalise the economy and retrench the welfare state with the commitment to social solidarity (Schmidt 2000).

Britain is somewhat different, given the strong emphasis on individual responsibility that is at the very foundations of its notion of citizenship, and given the minimal nature of the welfare state (with regard to social assistance, unemployment compensation, and the like) that developed in the post-war years. The neo-liberal Thatcherite discourse, moreover, only reinforced this individualistic and minimalist view of the welfare state, even if the cuts in social services have not been nearly as severe as the Thatcherite rhetoric claimed. It is telling that the renewal of the Thatcherite discourse with Blair's 'third way,' although more concerned with social equity issues with regard to the very poor, has nonetheless moved toward promoting even greater individual responsibility through reforms such as workfare (Schmidt 2000).

The economic changes related to European integration, in brief, have had a major impact on common expectations about the state's role and citizen responsibilities in Member States, undermining in many instances traditional discourses about economic organisation and social justice, albeit most in France, less in Germany, and least in Britain. The political institutional changes represent perhaps an even greater challenge than the economic challenge to expectations about the state's role, and pose even greater problems for traditional discourses about political democracy.

\section{The Challenges to Traditional Discourses about Political Democracy}

The problems for European Member States precipitated by Europe-related change are not just economic, involving the loss of state autonomy and control in the face of growing supranational authority and control over national economies and economic 
decision-making. They are also political, since the development of European governance structures and practices has served to transform national political structures and practices. European institutions strike at the very foundations of national political democracy by throwing into question which branches or units of government should have what sorts of responsibility for which kinds of decisions, as well as about who should rightfully participate in decision-making, at what stage of the process, in which ways, and with what degree of accommodation (see Schmidt 1999b).

The institutional changes, in short, challenge commonly-held, nationally specific notions not only about the appropriate amount of state institutional autonomy and control but also the acceptable process of policy-making and access to decisionmaking. More specifically, they alter expectations about how much power the executive should have over other institutional actors, for example, whether it should have minimal power over an independent judiciary - the German model which is also the European, but less so the British, and certainly not the French; whether it should allow greater independence to subnational units - again the German and European preference, to some extent the French preference, but certainly not the British until most recently; and whether it should ensure that the legislature lose no more power than it already has - the British and German insistence, but not of French concern or, in certain ways, European (given the interest in expanding European Parliamentary power even if this were to the detriment of national parliamentary power). Similarly, moreover, these institutional changes alter expectations about who should have access to policy-making and at what level or stage of the process, for example, whether policy formulation should allow interest access - the EU model which Germany approximates with participation for certain privileged interests but which France rejects on grounds of executive autonomy and Britain allows to a very minimal extent through Parliament; and whether policy implementation should forbid interest accommodation - again the EU model of regulation which allows no exceptions to the rules, but certainly not the French model which generally makes exceptions, or the British model, which prefers informal arrangements to codified rules (Schmidt 1997b, 1999b).

Adjustment to institutional change has not been easy for France, where the philosophical justification for extensive executive autonomy and control has its origins in Jacobin notions of the role of the state as the direct representative of the people, to do its bidding without obligation to any other authority (including the historically dependent judiciary, the traditionally weak legislature, and the steadily centrally controlled periphery) by formulating policy without intermediation by other actors (in particular organised interests, which have always been regarded as illegitimate if not organised by the state) and by implementing policy with administrative discretion (i.e. by accommodating interests where they deem it appropriate) (Schmidt 1996). The institutional changes related to the EU as well as internal dynamics that have increased the independence of the judiciary have made governmental elites in particular uncomfortable with the greater judicial activism that undermines executive decisionmaking autonomy and threatens jail for some executives (business as well as governmental). By contrast, the reaction to the greater independence of subnational authorities has been generally positive, given the dynamism that has proven a boon to local economic development, while the decrease in legislative power has occasioned relatively little reaction, even from the French Parliament.

The most problematic change for French democracy, however, has been the loss of administrative flexibility in implementation (Schmidt 1997b). For those interests that 
have never had much access at the national policy formulation stage and have not taken advantage of the greater European openness in policy formulation (whether for lack of access or organisation) now find themselves also increasingly cut out of the decision-making process at the national implementation stage (because of the impossibility of government accommodation), and are more likely to engage in confrontation where they perceive themselves to be negatively affected by European integration. Business interests, more specifically, have relatively little problem with the new European-dominated policy formulation process, since they are, and have been, present as an influential force at EU level for a long time. But the farmers upset by reductions in support which result, in particular, from international negotiations in the context of the GATT, the truckers angry about EU-mandated liberalisation, and most dramatically, in late 1995, the workers in the infrastructural 'service public' industries unhappy about cuts in social security and pension reforms related to the run-up to EMU (e.g. the rail workers) and also worried about privatisation and deregulation (e.g. employees of France Telecom and the banks) have been prone to strikes, protests, and job actions in response to their lack of access or input into the decisions that most affect them.

But the executive has not thought to diminish its own decision-making autonomy in the name of democratic participation and social peace for these interests, for example, by improving interest access to national policy formulation and even to European policy formulation via national channels to make up for the loss of accommodation in implementation. (Interestingly enough, it has done this for business interests, perhaps because there has always been a close relationship between business and government, whereas there has never been one between government and labour, while the relationship between government and agriculture has become more distant in recent years) (Schmidt 1999a). The executive has, on the contrary, focused on demonstrating that its loss of autonomy and flexibility to supranational EU authority is not so significant because France continues to predominate at the European level. National pride, in other words, and the traditional assumption that the state, in the form of the executive, will always be strong and powerful, and not corruptible by the particularity of interests, has so far precluded this kind of adjustment. And periodically, therefore, when it is clear that France does not predominate in the EU, the government, much to the displeasure of other Member States, falls back on making up for its loss of autonomy in policy formulation by demanding (albeit unsuccessfully) that Frenchmen play a major leadership role in Europe by commanding the southern fleet of NATO or heading the European Central Bank, in order for it to look at least as if the French have significant control over European institutions. Or the government seeks to cover over its loss of flexibility in policy implementation through such news-grabbing actions as the last minute defence of the farmers in the GATT negotiations and the push for an employment chapter in the last IGC that led to the Amsterdam Treaty. The discourse, in other words, has remained focused on presenting an image of state omnipotence to the French public which has only very recently begun to be moderated to some degree by Jospin.

In Britain, adjustment to institutional change has been somewhat less difficult than for France. This is not only because the government protected it more from institutional incursions through opt-outs, but also because the executive has great power in a more limited sphere. The British philosophical justification for extensive executive autonomy and control, which has its origins in the historical power of the monarchy, has since the Magna Carta been tempered by the historically evolving power of 
Parliament as well as in more recent times by a more independent judiciary. Thus, the British executive has found it easier to accept the increasing independence of the judiciary, but it has found it much harder to accept the loss in power of the somewhat more independent legislature, given the place of British Parliamentary sovereignty in the collective identity. This is why the British executive has time and again inveighed against the incursions of the EU on parliamentary powers, even though this is something of sleight of hand since the executive, as the representative of the parliamentary majority, has always held a tight rein over the parliament, and has therefore as often as not been protesting against EU incursions into its own autonomy when claiming to protect parliamentary prerogatives. The executive's power over subnational authorities, which was total until Blair's very recent reforms, is another matter entirely, and seems to have little to do with issues related to national identity, which may be why it was relatively easy for Thatcher to abolish local councils, and why Blair's reforms have not been greeted with nearly the enthusiasm he expected in either Scotland or Wales. Finally, even the loss of administrative flexibility in implementation, although also problematic for British democracy, is less significant than for the French, since interests have always had more informal access in policy formulation and have never been used to accommodate by way of making exceptions to formalised rules, given the traditionally greater independence of the judiciary and respect for the law.

What is most problematic for British political democracy within this context, however, is the formalisation of what had been informal before, and thus the increasing legalisation in areas that had traditionally been more the domain of 'gentlemen's agreements' and informal arrangements. The British have long prided themselves on their civility, that is, their ability to work out problems informally following long-established and long-accepted, but never formalised, rules-the best example of this being the lack of a written Constitution. The formalisation that accompanies Brussels' directives, and especially its insistence on compulsory, rather than voluntary, compliance rules, only encourages what the British see as the growing rigidification of a public domain which will only increase the likelihood of legal conflict as it undermines the traditional, informal process of conflict resolution. But because British governments have explicitly voiced their concerns about the contradiction between liberalisation and rigidification in their discourse, at least in relation to European integration, its impact may be less significant for British political democracy than the somewhat different contradictions faced by France, which French governments have yet to address directly.

In Germany, finally, adjustment to institutional change has been the least difficult so far. This is not only because the balance of powers has largely been maintained between the executive, which has never had much autonomy or control, and the legislature, the judiciary and subnational units, but also because the policy-making process where business and labour, as privileged interests, participate both in policy formulation and implementation has also not changed much. Moreover, because business, labour, and subnational units all have access to European policy-making via national channels (while business has it directly in addition), they have not felt cut out of the policy process in the way that many French interests have. This is not to suggest, however, that the maintenance of the balance of powers or the guarantee of national access to European policy-making came easily. On the contrary, a great deal of effort through national and EU negotiation has been expended to ensure that these institutional arrangements and practices remained intact. This has been primarily 
because of how important they are to the notions of political democracy built during the post-war period which value consensus and expect that the executive will not have too much autonomy or control, that the judiciary will be independent, that the subnational authorities will have a major say in relevant areas, and that business and labour will be partners in decision-making. For Germany, the fact that this consensus may be breaking down today has more to do with economic rather than institutional changes.

\section{Conclusion}

The ultimate success of the economic adjustments and institutional adaptations related to globalisation and European integration, then, depends in large measure on the ability of national discourses to legitimate such changes by justifying the alterations in economic organisation, in social welfare, and in political democracy while revising long-held understandings of national identity. But the task for national governments is a particularly difficult one. It is hard enough to construct and maintain a national legitimating discourse when policy elites largely have autonomy in their national policy-making and control over national actors. But with globalisation and European integration, they have lost significant autonomy and control not simply over the forces at work in the polity but over the very policies they can institute in response to those forces. And within these constraints, governments must find a way of legitimating change, by showing how the country's prospects are enhanced rather than diminished by the country's participation in a supranational economic system coordinated by a supranational governance authority to which it is increasingly subordinated and which alters national economic and institutional arrangements and practices.

Among the three major European countries, France, having undergone major economic and institutional transformation in response to global and European pressures, remains in search of a coherent discourse capable of legitimating those changes, although it appears closer to it with the Jospin government. By comparison, Britain, which anticipated many of the economic and institutional changes required by Europeanisation and successfully resisted others, managed to construct a coherent national discourse after Thatcher which is today in the process of renewal under Blair, as the country faces major institutional choices with regard to integration. And Germany, which had until lately been able to avoid change in consequence of its economic strength and its institutional organisation, has maintained a post-war discourse that is only today in the process of being recast, as the country faces major economic strains as a result of unification and globalisation.

\section{References}

Campbell, 'Institutional Analysis and the Role of Ideas in Political Economy', (1998) Theory and Society 1-33

Diez, 'Speaking 'Europe': The Politics of Integration Discourse,' (1999) 6:4 Journal of European Public Policy, supplement (September)

Dryzek and Leonard, 'History and Discipline in Political Science', (1998) 83 American Political Science Review 4.

Gottweis, Regulating Genetic Engineering in the European Union: A Post-Structuralist Perspective (Routledge 1999).

Guiraudon, Policy Change Behind Gilded Doors: Explaining the Evolution of Aliens' Rights in Contemporary 
Western Europe (1974-1994), PhD dissertation for the Department of Government, Harvard University (April 1997).

Haas, 'Introduction: Epistemic Communities and International Policy Coordination', (1992) 46 International Organization 1-35.

Habermas, The Structural Transformation of the Public Sphere, trans. Burger and Lawrence (MIT Press, 1989).

Habermas, 'Further Reflections on the Public Sphere', in Craig Calhoun (ed.), Habermas and the Public Sphere (MIT Press, 1992).

Hall, 'Policy Paradigms, Social Learning and the State: The Case of Economic Policy-Making in Britain', (1993) Comparative Politics 25.

Hall, 'Conclusion' in Peter A. Hall (ed.), The Political Power of Economic Ideas: Keynesianism across Nations (Princeton University Press, 1989).

Hay and Watson, 'Rendering the Contingent Necessary: New Labour's Neo-Liberal Conversion and the Discourse of Globalisation.' Paper prepared for presentation to the annual conference of the American Political Science Association (Boston, Sept. 3-6, 1998).

Hempel, Aspects of Scientific Explanation (Free Press, 1965).

Héritier, Knill and Mingers, Ringing the Changes in Europe: Regulatory Competition and Redefinition of the State. Britain. France, Germany (de Gruyter, 1996).

Hirschman, 'How the Keynesian Revolution was Exported from the United States, and other Comments', in Hall (ed.), Political Power of Economic Ideas.

Jobert, 'Représentations Sociales, Controverses et Débats dans la Conduite des Politiques Publiques', (1992) 42:2 Revue Française de Science Politique 219-234.

Katzenstein, Cultural Norms and National Security: Police and the Military in Post-war Japan (Cornell University Press, 1996).

Kohler-Koch, 'Organized Interests in European Integration: The Evolution of a New Type of Governance?', in A. Young and H. Wallace (eds), Participation and Policymaking in the European Union (OUP, 1997).

Kuhn, The Structure of Scientific Revolutions, (University of Chicago Press, 1970, second edition).

Lakatos, 'Methodology of Scientific Research Programmes', in Imre Lakatos and Alan Musgrave (eds), Criticism and the Growth of Knowledge (Cambridge University Press, 1970).

Larat, 'The Political Dimensions of Narrative'. Paper prepared for delivery at the 27th Annual ECPR Joint Session of Workshops (Mannheim University, 26-31 March 1999).

Lehmbruch, 'The Rise and Change of Discourses on 'Embedded Capitalism' in Germany and Japan and their Institutional Setting'. Paper prepared for presentation for the Workshop Project on Germany and Japan organised by Wolfgang Streeck and Ronald Dore (Max Planck Institute, Cologne, 24-26 June 1999).

Majone, Evidence, Argument and Persuasion in the Policy Process (Yale University Press, 1989).

March and Olsen, Democratic Governance (Free Press, 1995).

Muller, 'Les Politiques Publiques comme Construction d'un Rapport au Monde' in Alain Faure, Gilles Pollet and Philippe Warin (eds), La Construction du Sens dans les Politiques Publiques: Débats autour de la notion de Référentiel (L'Harmattan, 1995).

Mutz, Sniderman and Brody, Political Persuasion and Attitude Change (University of Michigan Press, 1996).

Pocock, 'The History of Political Thought', in Peter Laslett and W.G. Runciman (eds), Philosophy, Politics and Society (Blackwell, 1964, Second series).

Popper, Logic of Scientific Discovery (Basic, 1961).

Radaelli, 'The Power of Policy Narratives in the European Union: The Case of Tax Policy', in Dietmar Braun and Andreas Busch (eds), The Power of Ideas: Policy Ideas and Policy Change (Edward Elgar, forthcoming).

Reich (ed.), The Power of Public Ideas (Ballinger, 1988).

Rein and Schön, 'Frame-Reflective Policy Discourse', in P. Wagner, C. H. Weiss, B. Wittrock, and H. Wollman (eds), Social Sciences, Modern States, National Experiences, and Theoretical Crossroads (Cambridge University Press, 1991).

Risse, 'Who Are We? A Europeanization of National Identities?' Paper presented at the workshop on 'Europeanization and Domestic Change', European University Institute, 19-20 June 1998.

Roe, Narrative Policy Analysis: Theory and Practice (Duke University Press, 1994).

Sabatier, 'The Advocacy Coalition Framework: Revisions and Relevance for Europe', (1998) 5:1 Journal of European Public Policy 98-130

Sabatier and Jenkins-Smith (eds), Policy Change and Learning: An Advocacy Coalition Approach (Westview, 1993). 
Scharpf, Games Real People Play (Westview, 1997).

Schmidt, 'Four Approaches to Scientific Rationality', (1986) 19:3 Methodology and Science 207-232.

Schmidt, 'Four Approaches to Science and their Implications for Organizational Theory and Research', (1987) 9:1 Knowledge 19-41.

Schmidt, 'Four Models of Explanation' (1988) 21:3 Methodology and Science 174-201.

Schmidt, From State to Market? The Transformation of French Government and Business (Cambridge University Press, 1996).

Schmidt, 'Discourse and (Dis)Integration in Europe: The Cases of France, Britain, and Germany', (1997a) 126:3 Daedalus 167-198.

Schmidt, 'European Integration and Democracy: The Differences among Member States', (1997b) 4:1 Journal of European Public Policy 128-145.

Schmidt, 'The Changing Dynamics of State-Society Relations in the Fifth Republic', (1999a) West European Politics.

Schmidt, 'European "Federalism" and its Encroachments on National Institutions', (1999b) 29:1 Publius.

Schmidt, 'Discourse and the Legitimation of Economic and Social Policy Change', in Steven Weber (ed.), Globalization and the European Political Economy (Columbia University Press, forthcoming).

Schmidt, 'The Role of Values and Discourse in Welfare State Reform: The Politics of Successful Adjustment', in Fritz W. Scharpf and Vivien A. Schmidt (eds), Welfare and Work in the Open Economy: From Vulnerability to Competitiveness? (OUP, Volume I, 2000).

Schön and Rein, Frame Reflection. Toward the Resolution of Intractable Policy Controversies (Basic Books, 1994).

Singer, 'Policy Communities and Discourse Coalitions: The Role of Policy Analysis in Economic Policy-Making', (1990) 11 Knowledge: Creation, Diffusion, Utilization 428-458.

Skinner, 'Meaning and Understanding in the History of Ideas', in James Tully (ed.), Meaning and Context: Quentin Skinner and his Critics (Princeton University Press, 1988).

Surel, 'Les Politiques Publiques comme Paradigme', in Faure, Pollet and Warin (eds), La Construction du Sens.

Wittrock, Wagner and Wollmann 'Social Science and the Modern State: Knowledge, Institutions, and Societal Transformations', in Peter Wagner, Carol Hirschon Weiss and Hellmut Wollmann (eds), Social Sciences and Modern States: National Experiences and Theoretical Crossroads (Cambridge University Press, 1991).

Zaller, The Nature and Origins of Mass Opinion (Cambridge University Press, 1992). 